\title{
Developing Pictorial Multiple Intelligence Inventory for Students
}

\author{
Musyarrafah \\ Guidance and Counseling, Universitas Negeri Makassar, Indonesia \\ Email: asmarapalestine@gmail.com \\ Abdullah Pandang \\ Guidance and Counseling, Universitas Negeri Makassar, Indonesia \\ Email: abdullahpandang@unm.ac.id \\ Farida Aryani \\ Guidance and Counseling, Universitas Negeri Makassar, Indonesia \\ Email: farayani77@yahoo.com
}

(Diterima: 01-Maret-2019; direvisi: 10-April-2019; dipublikasikan: 28-Juni-2019)

\begin{abstract}
This study aims to (1) describe the need for pictorial multiple intelligence inventory for early grade students, (2) to find out the description of inventory forms, (3) to test usability, accuracy, and feasibility of the inventory, and (4) to know validity and reliability of the Inventory. The method of this research is development research by using the research stages of Borg and Gall development research. Data is collected through interviews, observation, and questionnaires, and the data were analyzed descriptively. The results showed that (1) inventory was needed by teachers and students in Darul Istiqamah Bongki, (2) The inventory was developed using orthogonal item extracts with choices Yes and No. The inventory consists of eight sessions representing each Multiple Intelligences. (3) the results of expert validation tests show inventory products included in the criteria are very useful, very feasible and very appropriate. (4) the results of the validity test using Product Moment Correlation also show good validity on inventory, while the results of the reliability test with Cronbach Alpha show an alpha value of $0.729>0.6$ so that inventory has good reliability. This means that the substance of the Pictorial Multiple Intelligences Inventory developed has met the criteria of useful, feasible and appropriate, valid and reliable so that it can be used as a tool to map the plural intelligence of early grade students.
\end{abstract}

Keywords: Multiple Intelligences, Inventory of Multiple Intelligences, pictorial inventory

(i) (5) This is an open access article under the CC BY-NC 4.0 license (http://creativecommons.org/licenses/by-nc-nd/4.0/).

\section{INTRODUCTION}

Intelligence is originated as intelligent. It means perfect of ingenuity (to think, to understand and others), perspicacious, and perfect of the body grow. Intelligence is categorized as intelligent, behavior to be smart and perfect of ingenuity (Kamus Besar Bahasa
Indonesia, 2017). In recent times, Indonesian society knows the intelligence concept as an intellectual factor. The society argues that people who have an intellectual capability will pursue success in the future.

Pasiak (2009) argues that in the educational system, most teachers think that 


\section{5 | Jurnal Psikologi Pendidikan \& Konseling Vol. 5 No. 1 Juni 2019}

intelligence is mere intellectual/cognitive capability. The evaluation system in education usually focused on intellectual capability. Students who have high skills in Math, English, and memorizing of the material subject.

Silen (2014) appended that the evaluation system usually focused on intellectual capability. In the same argumentation by Abas (2016) the educational evaluation system in Indonesia is limited to academic skill and it denies the process. The certain process produces a dichotomy in the class, also in the school. The certain process produces a ranking system that can make a judge for students as smart and stupid.

Pasiak (2009) rejected the argumentation of (Silen, 2014) that focusing on intellectual capability is outdated, this is because neuroscience has conducted research related to the intellectual intelligence pointed out that intellectual intelligence could not guarantee students successful in the future. Utami (2008) explained that intellectual intelligence is not a dominant predictor of the individual successful in the future.

Daniel Goleman (Utami dkk., 2018) appended IQ contributes approximately $20 \%$ of the successful, and the other factors such skill to motivate ourselves and how to survive in frustration and stress also empathy. Having said that, Zohar \& Marshall (Zohar \& Marshall, 2010) as a founder of spirituality quotient explain that spiritual quotient has a pivotal role in the student's success. The student who gets happiness in the learning process will get the better achievement.

It is also, Howard Gardner as a founder of multiple intelligence introduces aspects of intelligence. Multiple intelligences theory is defined capacity to solve the problems and create new products for a good and natural environment (Santioso, 2016). Gardner (Chatib, 2014) appended that intellectual capacity cannot be measured merely by psychological test, but it should be measured by observing individual habit to figure out their problem and their habit to create the new product which has cultural value.

Gardner (2003) has stated that intelligence is not a single part, but multiple parts, and it occurs in every person with 8 types of intelligence such as logical-mathematical, Linguistic, musical, visual-spatial, kinesthetic, naturalistic, interpersonal and intrapersonal.
Multiple intelligence theory claims that every person is a smart one, the difference is the type of intelligence that they have dominantly. A student can have logical-mathematical, having said that the others have musical or naturalistic intelligence dominantly. It is also, Supardi (2015) explains that every student has the potency to be different from others, because of that education should adjust to every student's condition. Munirah (2015) appended that teachers have responsibility from God to teach and educate students related to their talent, interest, and potency.

Every student has multiple intelligence, and the responsibility of the teacher is to map the student's multiple intelligence. Ismail (2018) has explained that understanding student's multiple intelligence brings through the teacher to stimulate student's intelligence in many ways. The teachers can look at the indicators from student's intelligence. Finally, the stimulation process can conduct in many ways. Knowledge related to intelligence will help teachers to optimize their comprehension related to student's multiple intelligence to be successful. Also, Gardner (2003) explains that knowing student's multiple intelligence will simplify schools to actualize the vision and mission of schools and help students to grasp their aims in the future.

The field study was conducted by the researcher in the Yayasan Pembina School in Sinjai such as Madrasah Ibtidaiyah Darul Istiqomah Bongki and Boarding School Darul Istiqamah Bongki in February 2018. The field study was conducted through interviews with the teachers pointed out that all teachers assumed that only some students are smart and the others are stupid.

The researcher collected data to find out students who get a bad judge, while the researcher conducted an interview session by focus group discussion (FGD). As per the interview session, the researcher pointed out that students who experienced as a stupid student are a student who interested with other learning materials (out of class material). Take a sample from Qaila (students grade III). She likes drawing and dreaming to be a designer. As a consequence, she likes drawing than writing learning material in the class. It is also, from Iyang (Student in the grade III), she prefers to memorize Al-Quran. According to Resky (student in grade III). She prefers to learn the Arabian language. Another one is Fais (students 
in the grade III), she prefers to sleep in the class than writing materials.

As per the FGD session, it can be concluded that students who experienced negative judgments from the teachers usually experienced high intonation from the teachers. Also, the students feel that the teacher does not like them, and prefer to the smart students. As a consequence of a certain condition, they usually go to the school reluctantly and experienced anxious when the teacher gives tasks for them in the class. If a certain conditions are continuous, student's self-esteem will be low and the will have paralyzing experience.

Can turn out the student's intelligence, such as bad experiences. Also, Miller (Amstrong, 2009) argues that yell, insult, and slurs which students experienced, can reduce their motivation to learn in their lifetimes. Bad experiences sometimes make students feel embarrassed, guilty, afraid, angry, and other negative emotions. If paralyzing experience happens continuously, the student intelligence potencies will fall over. Finally, the students will go through learning difficulties in their lifetimes. Therefore, it is needed for teachers to understand and to know every intelligence potency of their students. The teachers should understand that every intelligence which the students have, is different from one and another. Hence, the teachers consider that students are equal, appreciating every student, giving supports and motivation, also giving an opportunity for the students to escalate their intelligence on the learning process.

Every student has multiple intelligence will get many supports and it will help students to develop their intelligence. As per Beckman (Raharjo, 2010) argue that students will evolve their intelligence if they acquire enough facilities, enough spiritual and material supports, natural supports, far from the conflict and obtain enough opportunity to improve their intelligence in the learning process.

Giving opportunities for students to utilize their multiple intelligence can improve their learning achievement. According to McMahon, Rose, \& Parks, (2014) that several research results related to the integration of multiple intelligence on the learning process indicate that it can improve student's learning achievement. Related research from Baş (2016), Yaghoob \& Hossein (2016) on students in junior high school pointed out that, there is the improvement of student's learning achievement after the implementation of multiple intelligence on the learning process. It is also, research from Kandeel (2016) on the students from the Math Department at King Saud University to find out that the implementation of multiple intelligence in the learning process affects student's learning achievement. Also, Lazear (Hironaka-Juteau, 2017) explains that the enhancement of student's learning achievement is caused by the application of multiple intelligence theory on understanding learning material content comprehensively.

To correlate with academic achievement, multiple intelligence correlates with student's learning style Baleghizadeh and Shayeghi (2014); Şener and Çokçalışkan, 2018); (Rayesh, 2016). Certain research finds out that there is a positive and significant correlation between multiple intelligence and learning style. Having said that, every student has own intelligence, but it is not easy for such parents and teachers to know student's tendency of intelligence. On the theory of multiple intelligence, discovering ability is a process to point out student's intelligence through the searching method. Gardner and Hatch (1989) argue that children in the age of 4-5 years old can show their multiple intelligence profiles. On the other hand, Gardner (2003) explains that in the age of 3-7 years old, children can show their weaknesses and strengths on the type of multiple intelligence. As per Hartini's elucidation, in the intention of developing Formal Multiple Intelligences Assessment Instruments for children should be started from 4-6 years old (Jamaris Edwita, 2014).

Multiple intelligence inventory which will develop by the researcher is inventory for students in elementary school in the grade 1-3. The certain inventory consists of items that are equipped with colorful cartoon pictures. The inventory is expected to make students interested in it. Kurnia \& Guslinda (2018) appended that visual symbols fill in the lowest grade. It means that words are easier to understand than sentences. Therefore, multiple intelligence inventory which will evolve is colorful pictures.

\section{METHOD}

The method of the research is Research and Development by using Borg and Gall strategy. Samples of the research are students in 
the grade I-III in the MI Darul Istiqamah Bongki, Sinjai Utara.

Terms of the framework from some variable in this research are: (1) Development is defined as a sequence of designing, producing, valuing, and revising of a certain product. In this research, the product is a multiple intelligence inventory; (2) Multiple intelligence is a theory that divides intelligence to be 8 types. It consists of linguistic, mathematical intelligence, visualspatial, musical, kinesthetic, interpersonal, intrapersonal and naturalistic intelligence; (3) Figured multiple intelligence inventory is a method to understand individual intelligence which utilizes papers. The papers consist of pictures which students should give marks for suitable expression with their condition. The expressions are accompanied by pictures. The students should give marks when the expressions do not appropriate with their self.

Development procedures can be explained as follows: (1) The first step is a preliminary study such as library research and need assessment by using the interview method and focus group discussion. (2) Planning. This stage consists of developing an initial draft (prototype) inventory. The certain planning is evolved by preliminary study and the result of need assessment in the school. (3) Developing an initial product, designing concept, content, and developing pictures in the inventory. (4) Expert judger. In this stage, an expert validator is a counselor. The counselor validates the inventory through evaluating congruence between items and theory. It is also, validator to evaluate inventory by congruence between items and students. The next step is examining inventory for 15 students to find out the validity of the items. As a result of initial field trials, it can be concluded that 15 items are not valid from 54 items. 39 items are valid and it is evaluated in the second field trials for 38 students in the initial classes.

\section{RESULTS AND DISCUSSIONS}

The results of the preliminary study and need assessment point out that teacher paradigm which there two kinds of students such smart and stupid ones are not feasible in recent times. Every student is a smart one who has different intelligence with others. Smart students will experience positive experiences such as acceptance, recognition from their teachers. On the other side, stupid students will encounter negative experiences such as rude communication and rejection from their teachers. As a consequence of the condition, it is predicted the students who encounter negative experiences from their teachers will sustain paralyzing experience. Paralyzing experiences are student's obstacles to enhance their intellectual capacity. Therefore, the researcher considers pictorial multiple intelligence inventory that the inventory can change the teacher paradigm that every student is smart. The Inventory is expected can describe student's intelligence profiles particularly for students in the initial grades.

The inventory is developed which are consists of 39 items. The items are accompanied by pictorial cartoons. The construct of inventory is the orthogonal model and Guttman scale model (Yes-No). The result of expert validation points out that the average value of inventory is $82,6 \%$. It can be concluded that pictorial multiple intelligence inventory fulfilled a great appearance of inventory. It is also, the result of the utility test find out the average of utility is $86,7 \%$ and the result of the appropriateness test is $80,2 \%$ and accuracy test is $79,2 \%$. As per the certain average of tests, it can be concluded that pictorial multiple intelligence inventory for students in the initial grade in elementary school is feasible and appropriate to use.

The result of the construct validity test by using correlation $\mathrm{n}$ product moment in the first validation test for 15 students pointed out that 15 items are invalid and 39 items are valid. Students. The next, the valid items are tested for 38 students. The result of the trial test by using product moment analysis find out that the value of $r$ count $>r$ table is 0,3202 . Furthermore, as per the reliability test by using Alpha Cronbach grade is 0,729 . It is more than 0,6 . As per the data, it can be summarized that the pictorial multiple intelligence inventory is reliable to use.

\section{CONCLUSION AND SUGGESTION}

As per the explanation in the result and discussion, it can be summarized that (1) Pictorial multiple intelligence inventory for the initial grade in elementary school is needed for mapping students intelligence in MI Darul Istiqomah Bongki, (2) Pictorial multiple intelligence inventory was developed which consisted of 39 items with colorful cartoons. The inventory used the orthogonal construct and Gutman scale model, (3) Inventory product has 
useful, feasible and appropriate criteria, (4) The inventory has high validity and high reliability. The suggestion for the next researchers is, the researchers can develop particular multiple intelligence which quantifies one dimension of multiple intelligence.

\section{REFERENCES}

Abas, R. A. (2016). Konsep Kecerdasan Majemuk Perspektif Howard Gardner dan Penerapannya dalam Pembelajaran Pendidikan Agama Islam di Sekolah. Skripsi. Tidak Diterbitkan. Salatiga: Institute Agama Islam Negeri Salatiga.

Amstrong, T. (2009). Multiple Intelligences in the Classroom (Edisi Ketiga). Virginia USA: ASCD.

Baleghizadeh, S., \& Shayeghi, R. (2014). The relationship between perceptual learning style preferences and Multiple Intelligences among Iranian EFL learners. Innovations in Education and Teaching International, 51(3), 255-264.

Baş, G. (2016). The Effect of Multiple Intelligences Theory-Based Education on Academic Achievement: A MetaAnalytic Review. Educational Sciences: Theory \& Practice, 16(6), 1833-1864.

Chatib, M. (2014). Gurunya Manusia: Menjadikan Semua Anak Istimewa dan Semua Anak Juara. Bandung: Kaifa.

Gardner, H. (2003). Kecerdasan Majemuk (Multiple Intellogences) Teori dan Praktek. Batam: Interaksara.

Hironaka-Juteau, J. H. (2017). The Use of the Multiple Intelligences Inventory in the Classroom. SCHOLE: A Journal of Leisure Studies and Recreation Education, 21(1), 159-162.

Ismail, A. (2018). Pengembangan Instrumen Kecerdasan Naturalis Anak Usia Dini di Kabupaten Luwu Timur Provinsi Sulawesi Selatan. Jurnal Evaluasi Pendidikan, 9(1), 16-29.

Jamaris Edwita, M. (2014). Formal Multiple Intelligences Assessment Instruments for 4-6 Years Old Children. American Journal of Educational Research, 2(12), 1164-1174.

Kamus Besar Bahasa Indonesia. (2017) (Edisi keempat). Jakarta: Badan Pengembangan dan Pembinaan Bahasa, Kementrian Pendidikan dan Kebudayaan.

Kandeel, R. A. A. (2016). Multiple Intelligences Patterns among Students at King Saud University and Its Relationship with Mathematics' Achievement. Journal of Education and Learning, 5(3), 94-106.

Kurnia, R., \& Guslinda. (2018). MEDIA PEMBELAJARAN ANAK USIA DINI. Surabaya: Jakad Publishing.

McMahon, S. D., Rose, D. S., \& Parks, M. (2014). Multiple Intelligences and Reading Achievement: An Examination of the Teele Inventory of Multiple Intelligences. The Journal of Experimental Education, 73(1), 41-52.

Munirah. (2015). Sistem Pendidikan di Indonesia: Antara Keinginan dan Realita. Jurnal Auladuna, 2(2), 233245.

Pasiak, T. (2009). Unlimited Potency of the Brain: Kenali dan Manfaatkan Sepenuhnya. Bandung: Mizan.

Raharjo, A. T. (2010). Hubungan antara Multiple Intelligence dengan Prestasi Belajar Siswa Kelas XI di SMA Negeri 10 Malang. Jurnal Psikologi, 5(2), 311322.

Rayesh, E. E. P. (2016). Hubungan Gaya Belajar dengan Multiple Intelligences Siswa Berprestasi kelas IV dan V Kota Malang. (Skripsi. Tidak Diterbitkan). Universitas Islam Negeri Maulana Malik Ibrahim, Malang.

Santioso, L. L. (2016). Panduan Praktis Tes Minat dan Bakat Anak. Jakarta: Penebar Plus.

Şener, S., \& Çokçalışkan, A. (2018). An Investigation between Multiple 
Intelligences and Learning Styles. Journal of Education and Training Studies, 6(2), 125.

Silen, A. P. (2014). Pengaruh Kecerdasan Intelektual Kecerdasan Emosional dan Kecerdasan Spiritual terhadap Prestasi Akademik. Jurnal Bisnis dan Ekonomi, 21(2), 116-133.

Supardi. (2015). Arah Pendidikan di Indonesia dalam Tataran Kebijakan dan Implementasi. Jurnal Formatif. Jurnal Formatif, 2(2), 111-121.
Utami, N. P., Wilujeng, S. R., \& Ayu, K. (2018). Kecerdasan Emosional Sebagai Penunjang Prestasi Kerja. UNEJ eProceeding, 486-489.

Yaghoob, R. A., \& Hossein, Z. P. (2016). The correlation of multiple intelligences for the achievements of secondary students. Educational Research and Reviews, 11(4), 141-145.

Zohar, D., \& Marshall, I. (2010). Spiritual Capital: Wealth We Can Live By. Callifornia: Behret Kohler Publisher. 